This is the author's version of a work that was accepted for publication in Chemical engineering journal (Ed. Elsevier). Changes resulting from the publishing process, such as peer review, editing, corrections, structural formatting, and other quality control mechanisms may not be reflected in this document. Changes may have been made to this work since it was submitted for publication. A definitive version was subsequently published in Reino, C. and Carrera, J. "Low-strength wastewater treatment in an anammox UASB reactor: effect of the liquid upflow velocity" in Chem. Eng. J, vol. 313 (2017), p. 217-225. DOI 10.1016/j.cej.2016.12.051

\title{
Low-strength wastewater treatment in an anammox UASB reactor: effect of the
} liquid upflow velocity

Clara Reino and Julián Carrera

GENOCOV Research Group, Department of Chemical, Biological and Environmental Engineering, School of Engineering, Universitat Autònoma de Barcelona, Ed. Q-Campus UAB, 08193 Bellaterra, Barcelona, Spain

*Corresponding author: Tel. +34935812141

E-mail address: julian.carrera@uab.cat (J. Carrera)

\section{Abstract}

Two-stage systems have been proposed to overcome the drawbacks associated to the implementation of the autotrophic biological nitrogen removal process in the mainstream of urban wastewater treatment plants. In this study, an upflow anammox sludge blanket (UAnSB) reactor was successfully operated for 325 days treating a low-strength synthetic influent mimicking mainstream conditions. A nitrogen loading rate of up to $1.8 \pm 0.2 \mathrm{~g} \mathrm{~N}$ $\mathrm{L}^{-1} \mathrm{~d}^{-1}$ was achieved at $26^{\circ} \mathrm{C}$ and the nitrogen removal rate obtained $\left(1.7 \pm 0.1 \mathrm{~g} \mathrm{~N} \mathrm{~L}^{-1} \mathrm{~d}^{-}\right.$ ${ }^{1}$ ) resulted considerably higher than most of the previously reported values for systems treating low-strength wastewater at similar temperatures. Fluorescence in situ hybridization analysis showed a high enrichment in the anammox specie Candidatus Brocadia anammoxidans during the whole operation. The evolution of the granule diameter was followed throughout the operation of the UAnSB reactor and a direct correlation of the average granule diameter with the liquid upflow velocity $\left(\mathrm{V}_{\mathrm{up}}\right)$ was established, being the higher the $\mathrm{V}_{\text {up }}$, the bigger the granules. A stable granule diameter of $790 \pm 40 \mu \mathrm{m}$ was achieved by maintaining a $\mathrm{V}_{\text {up }}$ of $1.0 \pm 0.1 \mathrm{~m} \mathrm{~h}^{-1}$. The low $\mathrm{V}_{\text {ups }}$ applied avoid the use of effluent recirculation which would present a huge inconvenient to implement UAnSB reactors at real scale, however these low $\mathrm{V}_{\text {ups }}$ led to external mass 
transfer problems in the reactor. In spite of the mass transfer limitations, not only a high specific anammox activity $\left(0.26 \pm 0.02 \mathrm{~g} \mathrm{~N} \mathrm{~g}^{-1} \mathrm{VS} \mathrm{d}^{-1}\right)$ was achieved in the UASB reactor but also a high nitrogen removal $(80 \pm 3 \%)$.

\section{Keywords}

Anammox, mainstream, granules, upflow velocity, boundary layer

1. Introduction

The implementation of the autotrophic biological nitrogen removal (BNR) in the mainstream of urban wastewater treatment plants (WWTPs) has been proposed as the main alternative for achieving a neutral energy-consumer or even an energy-producer urban WWTP [1,2]. The neutral energy-consumer urban WWTP is based on the use of most of the entering organic matter to produce biogas (with the subsequent energy recovery) plus the reduction of aeration costs due to the lower oxygen requirements of the autotrophic BNR compared to the conventional BNR through nitrification and heterotrophic denitrification. Hence, it consists of a first step of high-rate organic matter removal and a second step of autotrophic BNR where the effluent of the first step is treated through the partial nitritation and anaerobic ammonium oxidation (anammox) processes. The autotrophic BNR can be implemented either in one single reactor (one-stage systems) or in two separated reactors (two-stage systems). Recently, many studies were focused on the implementation of autotrophic BNR treating low-strength wastewater by using one-stage systems [3-7], however these systems present some significant disadvantages: (i) low nitrogen removal rates achieved; (ii) destabilization of the partial nitritation in the long term; and (iii) competition for nitrite of nitrite oxidizing bacteria (NOB) and anammox bacteria with the subsequent destabilization of anammox process. Thus, the two-stage strategy has appeared as an alternative to overcome these problems, since allows a more stable performance and control of the partial nitritation and anammox processes [8-11].

The application of the anammox process at mainstream conditions (low-strength and low temperature) appears as a prerequisite for the implementation of a two-stage system for autotrophic BNR in urban WWTPs. Thus, many efforts have been made to achieve a successful start-up and operation of anammox reactors treating mainstream wastewater [12-16]. The main disadvantage of anammox process is the very long doubling time (1012 days) of the anammox bacteria $[17,18]$. This slow growth is even more troublesome at 
mainstream conditions because of (i) the low biomass growth rate due to the operation temperature under the optimum range and (ii) the low net biomass production due to the low nitrogen content of the stream [19]. Therefore, a high solids retention time (SRT) is needed to increase the biomass concentration in the system and guarantee the growth of anammox at mainstream conditions.

One efficient alternative to achieve a high SRT is the use of granular sludge [20-22]. Different reactor configurations have been proposed for achieving granular sludge under anaerobic conditions: sequencing batch reactors (SBRs), filters, expanded bed and fluidized bed reactors, among others [23]. However, the use of Upflow Anaerobic Sludge Bed (UASB) reactors appear as the most attractive alternative for the implementation of anammox process [24-26]. The main advantage over other reactors is that UASB reactors present a high biomass retention capacity which allows achieving extremely high loading rates, and furthermore, the requirements of area and reactor size are low. However, UASB reactors usually operate at upflow velocities as low as $0.5-1.5 \mathrm{~m} \mathrm{~h}^{-1}[27,28]$, which can trigger to external mass transfer limitations due to the lack of efficient mixing in the sludge bed.

Biomass granulation is a complex process that can be affected by different factors; either physical and chemical factors related to the process conditions applied, or even biological factors such as the cell-to-cell communication (quorum sensing) [23]. The selection pressure imposed on the sludge is one of the factors affecting granulation. Thus, the selection pressure theory hypothesizes that granulation process strongly depends on the continuous selection of sludge particles that occurs in the reactors, in such a way that high selection pressure would wash-out light and dispersed sludge while heavier sludge could be retained in the system [23,24]. The selection pressure may result from any environmental condition, such as temperature, $\mathrm{pH}$, hydraulic retention time, upflow velocity $\left(\mathrm{V}_{\mathrm{up}}\right)$, reactor configuration, etc. In the case of UASB reactors, selection pressure generally depends on the liquid $V_{\text {up }}$ and gas production, which affect to the shear force imposed to biomass. Thus, high liquid $\mathrm{V}_{\text {ups }}$ lead to high hydrodynamic shear forces which enhance the granulation process $[29,30]$.

Hence, to overcome the limitations associated to UASB reactors (specifically external mass transfer problems), a variant of UASB reactors, Expanded Granular Sludge Bed (EGSB) reactors, appeared as an alternative for implementing the anammox process. In this way, Lotti et al. [15] reported high nitrogen loading rates (NLRs) in an anammox 
EGSB reactor treating urban wastewater, even at $10^{\circ} \mathrm{C}$. In EGSB reactors, liquid $\mathrm{V}_{\text {ups }}$ are higher than $4 \mathrm{~m} \mathrm{~h}^{-1}$ to cause the granular sludge bed to expand [31]. For the implementation of the anammox process in EGSB such high $V_{\text {ups }}$ are achieved by recycling part of the effluent, i.e. a liquid recirculation is used. Nevertheless, the need of a liquid recirculation is problematic for the real-scale implementation of the anammox process in the mainstream of urban WWTPs since too high recirculation flows would be needed and, consequently, operational costs would be unacceptable. By now, few studies have focused on the effect of $\mathrm{V}_{\text {up }}$ on the operation of anammox UASB (UAnSB) reactors and besides, to the best of the authors' knowledge, all have focused on operations with high-strength wastewaters [32,33].

Therefore, this study aimed to (i) implement the anammox process in an UASB reactor treating a low-strength synthetic influent achieving high nitrogen removal rates and high effluent quality, and (ii) study in depth the effect of the liquid $V_{\text {up }}$ on the UAnSB reactor operation, specifically by following the granulation through the operation of the reactor.

\section{Material and methods}

\subsection{Reactor and experimental set-up description}

The anammox process was carried out in a lab-scale UASB reactor with a working volume of $2 \mathrm{~L}$ including the gas-liquid-solid separator. The inner diameter of the column was $51 \mathrm{~mm}$ and the total-reactor-height to column-diameter ratio was 12.5 . The detailed diagram of the reactor is present in Fig. 1. The $\mathrm{pH}$ was not controlled but measured offline and its value was $7.9 \pm 0.2$ during the whole operation, as the $\mathrm{pH}$ of the influent was set at $7.5 \pm 0.2$. Influent was devoid of oxygen since influent tank was periodically flushed with dinitrogen gas and additionally dinitrogen gas was introduced into the reactor headspace. DO concentration was measured in the bulk liquid of the reactor by means of a DO electrode (DO 60-50, Crison Instruments, Spain) and its value was always $0 \mathrm{mg} \mathrm{L}^{-}$

${ }^{1}$. The temperature was measured and controlled by means of an electric heater (HBSI 0.8m, HORST, Germany) connected to a temperature controller (BS-2400, Desin Instruments, Spain).

\subsection{Reactor operation}


The reactor operation was divided in four different periods, each one corresponding to a different NLR applied. The period I (days 0-50) corresponded to the start-up period when the NLR was gradually increased until a stable value was achieved. During period I, the temperature was controlled at $32^{\circ} \mathrm{C}$. Period II (days 50-200) corresponded to the stable operation at a fixed NLR. Period III (days 200-250) was a period of transition when NLR was gradually increased again, until achieving a stable value in Period IV (days 250-325). During periods II to IV, the temperature was controlled at $26^{\circ} \mathrm{C}$. NLR was changed by varying the inflow. Thus, changes in NLR led to changes in liquid $\mathrm{V}_{\text {up }}$ in the UAnSB reactor since the liquid $\mathrm{V}_{\text {up }}$ was only linked to inflow (no recirculation was used), so the periods of operation could also be related to the different $\mathrm{V}_{\mathrm{up}} \mathrm{s}$.

\subsection{Inoculum and synthetic wastewater}

The UAnSB reactor was inoculated with $500 \mathrm{ml}\left(13 \mathrm{~g} \mathrm{~L}^{-1}\right)$ of settled anammox granular biomass from an anammox SBR working at $35^{\circ} \mathrm{C}$ under stable conditions for more than one year [34]. The operational characteristics of the anammox SBR are shown in Table SI.1 in Supporting Information. The inoculum was enriched in anammox bacteria, more specifically in Candidatus Brocadia anammoxidans, with an abundance of $86 \pm 3 \%$ as analysed by fluorescence in situ hybridization (FISH). Candidatus Kuenenia stuttgartiensis was also analysed by FISH but not detected in the sample. On day 27 more biomass from the inoculum was added to the reactor to increase a $25 \%$ the sludge bed volume.

The UAnSB reactor was fed with a synthetic influent mimicking the effluent of a previous partial nitritation reactor treating a municipal low-strength wastewater as the one described in Reino et al. [11]. During periods I, II and III the synthetic influent contained $35 \mathrm{mg} \mathrm{N}-\mathrm{NH}_{4}{ }^{+} \mathrm{L}^{-1}$ in the form of $\left(\mathrm{NH}_{4}\right)_{2} \mathrm{SO}_{4}$ and $35 \mathrm{mg} \mathrm{N}-\mathrm{NO}_{2}{ }^{-} \mathrm{L}^{-1}$ in the form of $\mathrm{NaNO}_{2}$, which meant a nitrite to ammonium concentrations ratio of 1 . However, from day 244 onwards the nitrite to ammonium concentrations ratio in the influent was increased until $1.20 \pm 0.06$ to adjust the substrate concentrations to the reported anammox stoichiometry [21], resulting in average concentrations of $33 \mathrm{mg} \mathrm{N}^{-N_{4}}{ }^{+} \mathrm{L}^{-1}$ and $38 \mathrm{mg} \mathrm{N}-\mathrm{NO}_{2}{ }^{-} \mathrm{L}^{-1}$. In addition, $1000 \mathrm{mg} \mathrm{KHCO} \mathrm{L}^{-1}, 50 \mathrm{mg} \mathrm{NaH}{ }_{2} \mathrm{PO}_{4} \mathrm{~L}^{-1}, 100 \mathrm{mg} \mathrm{CaCl} 2 \cdot 2 \mathrm{H}_{2} \mathrm{O} \mathrm{L}^{-1}, 200 \mathrm{mg}$ $\mathrm{MgSO}_{4} .2 \mathrm{H}_{2} \mathrm{O} \mathrm{L} \mathrm{L}^{-1}, 6.3 \mathrm{mg} \mathrm{FeSO} \mathrm{L}^{-1}, 6.3 \mathrm{mg}$ EDTA L L ${ }^{-1}$ and $1.25 \mathrm{~mL} \mathrm{~L}^{-1}$ of a trace elements solution [35] were supplied to the synthetic influent. 


\subsection{Analytical methods}

Ammonium concentration was measured off-line with an ammonium analyser (AMTAX sc, Hach Lange, Germany), nitrite and nitrate concentrations were analysed with ionic chromatography using an ICS-2000 Integrated Reagent-Free IC system (DIONEX Corporation, USA). Mixed liquor total solids (TS) and mixed liquor volatile solids (VS) were analysed according to Standard Methods [36]. Average particle size and particle size distribution were measured by a laser particle size analysis system (Malvern Mastersizer Series 2600, Malvern instruments Ltd., UK). Sampling for size analysis was always performed at $145 \mathrm{~mm}$ of height of the UAnSB reactor, except in the case of the stratification studies when the sampling point was specified in the corresponding section of the results. Settling velocity was determined for at least 30 individual granules by dropping an individual granule in a glass cylinder containing tap water and measuring the time spent settling a known distance. Maximum specific anammox activity (SAA) was determined by measuring the overpressure generated by the anammox sludge in closed bottles according to the methodology described by Dapena-Mora et al. [37]. During this protocol to determine maximum SAA, bottles were maintained in a shaker at $150 \mathrm{rpm}$ to favour mixing and reduce external mass transfer limitations. Specific anammox activity in the UAnSB reactor (sNRR) was calculated by dividing the average volumetric nitrogen removal rate (NRR) of each period between the average biomass concentration in the sludge bed of the reactor.

\subsection{Fluorescence in situ hybridization (FISH) analysis}

Relative abundances of anammox bacteria were analysed by FISH technique coupled with confocal laser scanning microscopy (CLSM). Specific probes for Candidatus Brocadia anammoxidans and Candidatus Kuenenia stuttgartiensis were 5'-TxRedlabeled. Hybridizations were performed with the specific and general probes described in Table SI.2 in Supporting Information. Biomass samples were grabbed of the reactor and granules were crushed by means of a mortar and a pestle in order to facilitate hybridizations. A Leica TCS-SP5 confocal laser scanning microscope (Leica Microsystem Heidelberg GmbH; Mannheim, Germany) using a Plan-Apochromatic 63x 
objective (NA 1.4, oil) was used to quantify biomass by analysing at least 30 fields and following an automated procedure as described in Jubany et al. [38].

\subsection{Calculations}

The nitrogen removal rate (NRR) was calculated as the removal of substrates (ammonium and nitrite) without considering the nitrate produced in the anammox reaction. Conversely, nitrate produced was considered for the calculation of the nitrogen removal efficiency (NRE), since this parameter is more accurate to talk about N-removal from a real implementation point of view. Liquid $\mathrm{V}_{\text {up }}$ (in $\mathrm{m} \mathrm{h}^{-1}$ ) was determined with the inflow rate $\left(\mathrm{Q}\right.$, in $\left.\mathrm{m}^{3} \mathrm{~h}^{-1}\right)$ and the cross-sectional area of the reactor $\left(\mathrm{A}\right.$, in $\left.\mathrm{m}^{2}\right)$, as follows:

$$
V_{u p}=\frac{Q}{A}
$$

According to film theory model, mass transfer between the bulk liquid and the granule (or external mass transfer) is driven by a concentration gradient across an external boundary layer $\left(\mathrm{L}_{\mathrm{L}}\right.$, in $\left.\mathrm{m}\right)$. The mass flow of a component in the $\mathrm{L}_{\mathrm{L}}$ is proportional to the difference between the component concentration in the bulk liquid and the granule surface, with the proportionality constant being the external mass transfer coefficient $\left(\mathrm{k}_{\mathrm{c}}\right.$, in $\left.\mathrm{m} \mathrm{d}^{-1}\right)[39,40]$. Then, the mass transfer coefficient is:

$k_{c}=D_{F} /_{L_{L}}$

where $D_{F}$ is the diffusion coefficient for substrate in water $\left(\right.$ in $\left.\mathrm{m}^{2} \mathrm{~h}^{-1}\right)$.

For slow flow velocities or low turbulence, the value of $\mathrm{L}_{\mathrm{L}}$ is large (high external mass transfer limitations) while for fast flow or high turbulence, $\mathrm{L}_{\mathrm{L}}$ is small (low external mass transfer limitations). Both parameters $\left(\mathrm{k}_{\mathrm{c}}\right.$ and $\left.\mathrm{L}_{\mathrm{L}}\right)$ are usually calculated from experimental correlations [40]. For example, for laminar hydraulic flows around spherical particles, the following correlation can be used:

$S h=2+0.6 * R e^{1 / 2} * S c^{1 / 3}$

where Sh is the non-dimensional Sherwood number, Re is the non-dimensional Reynolds number and Sc is the non-dimensional Schmidt number.

Sherwood, Reynolds and Schmidt numbers are defined as:

$S h=\frac{k_{c} * d_{g}}{D_{F}}$ 
$R e=\frac{d_{g} * \rho_{w} * V_{u p}}{\mu_{w}}$

$S c=\frac{\mu_{w}}{D_{F} * \rho_{w}}$

where $\mu_{\mathrm{w}}$ is the water viscosity (in $\mathrm{kg} \mathrm{m}^{-1} \mathrm{~h}^{-1}$ ), $\rho_{\mathrm{w}}$ is the water density (in $\mathrm{kg} \mathrm{m}^{-3}$ ), $\mathrm{d}_{\mathrm{g}}$ is the average granule diameter (in $\mathrm{m}$ ) and $\mathrm{V}_{\text {up }}$ is the upflow liquid velocity (in $\mathrm{m} \mathrm{h}^{-1}$ ).

\section{Results and Discussion}

\subsection{Operation of the UAnSB reactor}

The lab-scale UAnSB reactor was inoculated (day 0) with anammox biomass from a SBR which was operating at $35^{\circ} \mathrm{C}$ with an average maximum SAA of $0.25 \pm 0.02 \mathrm{~g} \mathrm{~N} \mathrm{~g}^{-1} \mathrm{VS}$ $\mathrm{d}^{-1}$ [34]. During the start-up period (days 0-50) NLR was gradually increased from 0.09 to $0.78 \mathrm{~g} \mathrm{~N} \mathrm{~L}^{-1} \mathrm{~d}^{-1}$ and NRE fluctuated between $73 \%$ and $84 \%$ until stable operation was achieved from day 50 onwards with an average NRE of $76 \pm 3 \%$ on period II. Table 1 reports the operational parameters corresponding to different periods of operation of the UAnSB reactor. During period II the reactor was operated for 150 days at an average NLR of $0.8 \pm 0.2 \mathrm{~g} \mathrm{~N} \mathrm{~L}^{-1} \mathrm{~d}^{-1}$ and an average NRE of $76 \pm 3 \%$. Furthermore, in period IV the reactor achieved a stable operation for more than 2 months with an average NLR of $1.8 \pm 0.2 \mathrm{~g} \mathrm{~N} \mathrm{~L}^{-1} \mathrm{~d}^{-1}$ and a better NRE $(80 \pm 3 \%)$.

The nitrite to ammonium consumption ratio and the nitrate produced to ammonium consumed ratio increased during operation until period IV, achieving average values of $1.20 \pm 0.08$ and $0.26 \pm 0.03$, respectively. These average values are close to the previously reported for anammox cultures [21,41]. At the end of period III (on day 244) the nitrite to ammonium concentrations ratio in the influent was increased from 1.0 to 1.2 and an improvement of the ammonium removal efficiency was observed in the UAnSB reactor. In view of that, although nitrite was always observed in the effluent $\left(3.8 \pm 0.9 \mathrm{~g} \mathrm{~N}^{-\mathrm{NO}_{2}}{ }^{-}\right.$ $\mathrm{L}^{-1}$ ), the reactor was limited by nitrite during periods I, II and III, probably due to external mass transfer problems in the sludge bed.

The achieved NRR value in the UAnSB reactor $\left(1.7 \pm 0.1 \mathrm{~g} \mathrm{~N} \mathrm{~L}^{-1} \mathrm{~d}^{-1}\right.$ in period IV) was considerably higher than most of the previously reported values for systems treating lowstrength wastewater at similar temperatures. Table 2 shows the NRR achieved in both, 
one and two-stage systems. On the one hand, NRR achieved in this study was much higher than any NRR reported in one-stage systems. On the other hand, regarding two-stage systems, the NRR achieved in this study was comparable to the one obtained by Lotti et al. [15] in an anammox EGSB reactor (1.40-1.85 $\mathrm{g} \mathrm{N} \mathrm{L}^{-1} \mathrm{~d}^{-1}$ at $\left.20^{\circ} \mathrm{C}\right)$ and only lower than the reported by Ma et al. [16] $\left(5.7 \mathrm{~g} \mathrm{~N} \mathrm{~L}^{-1} \mathrm{~d}^{-1}\right.$ at $\left.30^{\circ} \mathrm{C}\right)$ which was achieved in a UAnSB reactor operating at a $\mathrm{V}_{\text {up }}$ as high as $11 \mathrm{~m} \mathrm{~h}^{-1}$. Probably, the higher NRR achieved by Ma et al. [16] was strongly correlated to the high $\mathrm{V}_{\text {up }}$ applied in its reactor, which favoured mixing and thus, overcame external mass transfer limitations in the sludge bed. Both Lotti et al. [15] and Ma et al. [16] operated reactors treating a real urban wastewater, which usually presents more disadvantageous conditions for the anammox process than a synthetic influent. In any case, the extremely high nitrogen removal rate obtained in this study compared to other similar studies (Table 2) is promising to confront the treatment of a real matrix of urban wastewater and also the decrease of temperature occurred in the main water line of urban WWTPs during winter. In fact, one of the big challenges operating anammox reactors at mainstream conditions is to achieve high nitrogen removal rates at low temperature.

Biomass concentration of the sludge bed in the UAnSB reactor was stable throughout the study, with an average value of $6.3 \pm 0.4 \mathrm{~g} \mathrm{VS} \mathrm{L}^{-1}$. The sludge had a high inorganic content since the VS/TS ratio was $0.48 \pm 0.05$. Biomass concentration in the effluent accounted for less than $9 \mathrm{mg} \mathrm{VS} \mathrm{L}^{-1}$ resulting in a SRT of $45 \pm 15$ days. Regarding to the settling properties of the granules, a good settling ability was observed during the whole operation, with an increase of the settling velocity from $19 \pm 5 \mathrm{~m} \mathrm{~h}^{-1}$ in period II to $31 \pm$ $9 \mathrm{~m} \mathrm{~h}^{-1}$ in period IV. Settling velocities achieved were in the range of the corresponding to granular biomass (from 20 to $150 \mathrm{~m} \mathrm{~h}^{-1}$, [47]).

Regarding the microbiological characterization of the sludge, FISH-CSLM was used to determine the enrichment in anammox bacteria during the whole operation of the UAnSB reactor. Thus, biomass samples on day 0 (inoculum), day 117 (period II) and day 314 (period IV) were analysed. On the one hand, Candidatus Brocadia anammoxidans was found to be the predominant microbial specie in the sludge bed, with percentages of the total population of $86 \pm 3 \%$ (day 0), $92 \pm 2 \%$ (day 117) and $93 \pm 2 \%$ (day 314). Hence, a high enrichment in anammox bacteria was maintained in the granular sludge bed throughout the study. On the other hand, Candidatus Kuenenia stuttgartiensis appeared 
at the end of the operation of the UAnSB reactor $(1 \pm 1 \%$ on day 314$)$ although it was not detected in the inoculum nor in the sample of day 117.

\subsection{Effect of the liquid upflow velocity on the operation of the UAnSB reactor}

\subsubsection{Granulation}

The evolution of the granule diameter was followed during the study (Fig. 2C). The inoculum had an average diameter of $920 \pm 90 \mu \mathrm{m}$, however during period I (start-up) and the beginning of period II the granule size decreased gradually until reaching a minimum value of $350 \pm 10 \mu \mathrm{m}$ after 100 days of operation. The slight increase of diameter on day 46 was due to the addition of new biomass from the inoculum on day 27. After day 105, the granule diameter started to increase until reaching an average stable value of $790 \pm 40 \mu \mathrm{m}$ from day 220 onwards. Additionally, Fig. 2C shows the fraction of biomass considered as granule, i.e. particle diameter bigger than $200 \mu \mathrm{m}$, which resulted higher than $70 \%$ during the whole operation of the UAnSB reactor, even when the granulation was dropping. Moreover, Fig. 3 shows the granule size distribution at different reactor operation days. The unimodal shape was maintained despite of the first decrease and later increase of the mean diameter, so there was mainly only one type of granule and the homogeneity of the sludge was maintained during the operation.

It is known that high $V_{\text {ups }}$ favour granulation in UASB reactors [29,30] and, in fact, a correlation of the mean granule diameter with the liquid $\mathrm{V}_{\text {up }}$ was determined with data of periods II, III and IV when the granule size was increasing (Fig. 4). It can be observed that there was a direct correlation $\left(\mathrm{R}^{2}=0.86\right)$ between both parameters. Moreover, two statements can be established from Fig. 4: (i) in the range $0.4-0.6 \mathrm{~m} \mathrm{~h}^{-1}$, higher upflow velocities enhanced granulation leading to higher granule diameters and (ii) there was a range of upflow velocities (from $0.8 \mathrm{~m} \mathrm{~h}^{-1}$ onwards) from which the granule diameter reached a maximum stable value. Nevertheless, despite of the liquid $\mathrm{V}_{\text {up }}$ was gradually increased during period I of operation, the average granule diameter decreased significantly (Fig. 2B and 2C), and thus, data from period I were not considered for the correlation of Fig. 4. The decreasing in granule size could be explained because the range of $\mathrm{V}_{\text {ups }}$ between 0-0.4 $\mathrm{m} \mathrm{h}^{-1}$ was not high enough to maintain granulation, but once $\mathrm{V}_{\text {up }}$ was higher in period II $\left(0.4-0.6 \mathrm{~m} \mathrm{~h}^{-1}\right)$ the drop in granule size was stopped and, after some time operating under this higher range, the average granule diameter started to 
increase. This meant that $\mathrm{V}_{\text {up }}$ was not a parameter with immediate effect on the granulation, i.e. some time was needed to notice its effect. In addition to the low $V_{\text {up }}$ applied in period I, the change of the biomass of the inoculum from an SBR to an UASB reactor could also be a reason to explain the dropping in granule size. The settling time imposed to the biomass is the driving force to favour granulation in SBRs, while in the case of UASB reactors the driving force is the liquid $V_{\text {up }}$ (Fig. 4). Hence, the change in the type of stress induced to the granules could contribute to the destabilization and decrease in granule diameter during start-up and the beginning of period II.

As previously mentioned, the effect of $\mathrm{V}_{\text {up }}$ on the granulation was evident but not immediate noticeable. Thus, during period III the $\mathrm{V}_{\text {up }}$ was sharply increased and as a result, the diameter of the granules increased until reaching a stable value in period IV (average value of $790 \pm 40 \mu \mathrm{m}$ at $1.0 \pm 0.1 \mathrm{~m} \mathrm{~h}^{-1}$ ) (Fig. 2). However, throughout these periods, a stratification of the granular sludge was visually observed along the longitude of the reactor; there were big granules at the bottom and smaller granules at the top. Therefore, sludge samples were taken and analysed at different heights of the UAnSB reactor (at 50, 145, 240, 345 and $450 \mathrm{~mm}$ of height) in order to confirm that the observed stratification was a fact indeed. Fig. 5 shows the average granule diameter at different heights of the UAnSB reactor during different operation days from the beginning of period III to the end of period IV ( $\mathrm{V}_{\text {up }}$ of $0.6-0.9 \mathrm{~m} \mathrm{~h}^{-1}$ in period III and $0.9-1.2 \mathrm{~m} \mathrm{~h}^{-1}$ in period IV). On the one hand, a clear difference between granule diameters along the heights of the reactor was observed from day 203 to 248, with consecutive increases of diameter in consecutive decreases of height. This difference was more evident comparing the three lower heights $(50,145,240 \mathrm{~mm}$ ) versus the two highest heights (345 and 450 $\mathrm{mm}$ ). On the contrary, samples of days 263 and 292 showed similar average diameters along the reactor heights, demonstrating the homogenization of diameters through the sludge bed of the UAnSB reactor. Hence, in period IV not only the average granule diameter was stabilized (Fig. 2C) but also the stratification of the sludge bed was eradicated. Therefore, the increase in granule diameters caused by the operation of the UAnSB at high $\mathrm{V}_{\text {ups }}$ was progressive and stratified along the reactor which indicated that the granule stabilization was a long process where almost 100 days were needed to achieve a sludge bed stable in size and not stratified (Fig. 5).

The improvement of the granulation process at high liquid $\mathrm{V}_{\text {ups }}$ was reported before. Alphenaar et al. [29] compared granulation in two UASB reactors performing anaerobic 
treatment of sulphate-containing wastewater and observed considerably higher granule diameters in the reactor with higher $\mathrm{V}_{\text {upS }}\left(0.5 \mathrm{~mm}\right.$ with $0.05 \mathrm{~m} \mathrm{~h}^{-1}$ and $1.2 \mathrm{~mm}$ with 0.65 $\mathrm{m} \mathrm{h}^{-1}$ ). Regarding anammox reactors, Ma et al. [16] operated an UAnSB reactor treating low-strength urban wastewater and observed the improvement of granulation when the $\mathrm{V}_{\text {up }}$ increased from 1.26 to $11 \mathrm{~m} \mathrm{~h}^{-1}$ at $30^{\circ} \mathrm{C}$. Even higher $\mathrm{V}_{\text {ups }}\left(20 \mathrm{~m} \mathrm{~h}^{-1}\right)$ were used by Lotti et al. [15] in a lab-scale EGSB reactor treating also low-strength urban wastewater. However, high recirculation of the effluent was needed to achieve these elevated $V_{\text {ups. }}$ Such high recirculation ratios (a recirculation ratio of 39 was used by Lotti et al. [15]) would present a huge inconvenient to implement UAnSB reactors at real scale, since too high pumping costs would be associated. In this study, substantially lower $\mathrm{V}_{\text {ups }}\left(0.8 \mathrm{~m} \mathrm{~h}^{-}\right.$

${ }^{1}$ ) were needed to maintain granulation and stable operation of an UAnSB reactor treating a low-strength synthetic wastewater. This would imply that no recirculation is needed and thus, a more realistic implementation of the process in an urban WWTP would be possible.

\subsubsection{External mass transfer limitations}

In UASB reactors, liquid $\mathrm{V}_{\text {up }}$ not only affects to granulation process but also to the external mass transfer in the system. Low $\mathrm{V}_{\text {ups }}$ can lead to insufficient mixing which produce external mass transfer limitations and, hence, substrate accumulation in the effluent. But also too high $\mathrm{V}_{\text {ups }}$ can lead to the formation of preferential flows that contribute to external mass transfer limitations as well. In fact, Lotti et al. [15] reported external mass transfer limitations in an EGSB reactor treating urban wastewater due to the formation of preferential flows, regardless of using high liquid $\mathrm{V}_{\text {ups }}\left(20 \mathrm{~m} \mathrm{~h}^{-1}\right)$. Thus, high substrate concentrations were accumulated in the EGSB reactor $\left(14 \pm 9 \mathrm{mg} \mathrm{N}-\mathrm{NH}_{4}{ }^{+}\right.$ $\mathrm{L}^{-1}$ and $13 \pm 11 \mathrm{mg} \mathrm{N}-\mathrm{NO}_{2}^{-} \mathrm{L}^{-1}$ ) of the reported study.

Table 3 shows the values of Reynolds ( $\mathrm{Re}$ ) and Sherwood (Sh) numbers, boundary layer $\left(\mathrm{L}_{\mathrm{L}}\right)$ and transfer coefficient $(\mathrm{kc})$ calculated for each operational period of the UAnSB reactor of this study. Before to discuss the calculations made to quantify the external mass transfer limitations, it is important to note that: (i) the nitrite concentration in the bulk liquid was never lower than $2.5 \mathrm{mg} \mathrm{N}-\mathrm{NO}_{2}{ }^{-} \mathrm{L}^{-1}$, showing that the performance of the UAnSB reactor was probably affected by mass transfer limitations and (ii) Re values indicate that the liquid flow in the UAnSB reactor was clearly laminar for any $\mathrm{V}_{\text {up }}$ used in this study, and consequently, Sh number can be calculated with Eq. (3). 
Regarding the calculations of the external mass transfer limitations, Table 3 shows that as $\mathrm{V}_{\text {up }}$ increased, Re and $\mathrm{Sh}$ numbers increased. This could result in an improvement of the external mass transfer from the bulk liquid to the granule as reflected in the increase of the achieved NRR. However, this improvement in the external mass transfer was not reflected in the values of the mass transfer coefficient $\left(\mathrm{k}_{\mathrm{c}}\right)$ and the boundary layer $\left(\mathrm{L}_{\mathrm{L}}\right)$. In fact, the highest $\mathrm{k}_{\mathfrak{c}}$, and consequently, the lowest $\mathrm{L}_{\mathrm{L}}$ were achieved in period II with a $\mathrm{V}_{\text {up }}$ half than the used in period IV. Both values $\left(\mathrm{k}_{\mathrm{c}}\right.$ and $\left.\mathrm{L}_{\mathrm{L}}\right)$ not only depend on $\mathrm{V}_{\text {up }}$ but also depend on granule diameter $\left(\mathrm{d}_{\mathrm{g}}\right)$. From Eqs. (2-6), it can be deduced that as $\mathrm{d}_{\mathrm{g}}$ increases, $\mathrm{k}_{\mathrm{c}}$ decreases and $\mathrm{L}_{\mathrm{L}}$ increases, that is, external mass transfer limitations increase. Consequently, when $\mathrm{V}_{\text {up }}$ and $\mathrm{d}_{\mathrm{g}}$ jointly increase, as it happened in periods IIIV, there exist two opposite effects over the external mass transfer. In this study, both opposite effects caused that $\mathrm{L}_{\mathrm{L}}$ values were quite similar in periods II, III and IV. In any case, $L_{L}$ values were always in the range 160-200 $\mu \mathrm{m}$, indicating that the UAnSB was always affected by external mass transfer limitations. In fact, substrate concentrations were always present in the effluent, with average values of $3 \pm 1 \mathrm{mg} \mathrm{N}-\mathrm{NH}_{4}{ }^{+} \mathrm{L}^{-1}$ and 3.5 $\pm 0.8 \mathrm{mg} \mathrm{N}-\mathrm{NO}_{2}{ }^{-} \mathrm{L}^{-1}$. Besides, maximum SAA tests showed an average value of $0.35 \pm$ $0.02 \mathrm{~g} \mathrm{~N} \mathrm{~g}^{-1} \mathrm{VS} \mathrm{d}^{-1}$ in period IV, while specific NRR in the UAnSB reactor was of 0.26 $\pm 0.02 \mathrm{~g} \mathrm{~N} \mathrm{~g}^{-1} \mathrm{VS} \mathrm{d}^{-1}$ during the same period. Maximum SAA tests were performed in bottles under continuous agitation, which enhanced mixing and reduced external mass transfer limitations. Hence, the difference between maximum SAA and specific NRR also demonstrated that the UAnSB reactor was affected by external mass transfer limitations.

Nevertheless, despite of the fact that the UAnSB reactor of the present study presented external mass transfer limitations, the resulting operation with a NRR of $1.7 \pm 0.1 \mathrm{~g} \mathrm{~N} \mathrm{~L}^{-}$ ${ }^{1} \mathrm{~d}^{-1}$, a NRE of $80 \pm 3 \%$ and a successful anammox granulation demonstrated that UASB reactors appear as a good alternative to implement the anammox process when a synthetic low-strength influent was treated. In any case, further research is needed to evaluate the UASB as an alternative to implement the anammox process at mainstream conditions focused on the treatment of a real influent at low temperature.

\section{Conclusions}

Stable anammox reaction was maintained in an UASB reactor treating a low-strength synthetic wastewater. Significantly high NLR, NRR and NRE were achieved compared 
to other similar systems. The anammox culture was highly enriched in Candidatus Brocadia anammoxidans during the whole operation of the reactor.

Liquid upflow velocity was demonstrated to be a key parameter to be aware of for the implementation of the anammox process in UASB reactors, since it affected to granulation and external mass transfer. On the one hand, liquid $\mathrm{V}_{\text {up }}$ presented a direct but not immediate effect on the anammox granulation, being the higher the $\mathrm{V}_{\text {up }}$ the bigger the granules. On the other hand, the low liquid $\mathrm{V}_{\text {ups }}$ applied led to external mass transfer limitations which in any case affected to the high nitrogen removal of the UAnSB.

Acknowledgements

This work was supported by the Spanish Ministerio de Economía y Competitividad (CTQ2014-60495-R) with funds from the Fondo Europeo de Desarrollo Regional (FEDER). The authors are members of the GENOCOV research group (Grup de Recerca Consolidat de la Generalitat de Catalunya, 2014 SGR 1255).

5. References

[1] B. Kartal, J.G. Kuenen, M.C.M. van Loosdrecht, Sewage Treatment with Anammox, Science (80-. ). 328 (2010) 702-703. doi:10.1126/science.1185941.

[2] H. Siegrist, D. Salzgeber, J. Eugster, A. Joss, Anammox brings WWTP closer to energy autarky due to increased biogas production and reduced aeration energy for N-removal, Water Sci. Technol. 57 (2008) 383-388. http://wst.iwaponline.com/content/57/3/383.abstract.

[3] H. De Clippeleir, S.E. Vlaeminck, F. De Wilde, K. Daeninck, M. Mosquera, P. Boeckx, W. Verstraete, N. Boon, One-stage partial nitritation/anammox at $15^{\circ} \mathrm{C}$ on pretreated sewage: feasibility demonstration at lab-scale., Appl. Microbiol. Biotechnol. 97 (2013) 10199-210. doi:10.1007/s00253-013-4744-x.

[4] E.M. Gilbert, S. Agrawal, S.M. Karst, H. Horn, P.H. Nielsen, S. Lackner, Low Temperature Partial Nitritation/Anammox in a Moving Bed Biofilm Reactor Treating Low Strength Wastewater, Environ. Sci. Technol. 48 (2014) 8784-8792. doi:10.1021/es501649m.

[5] Z. Hu, T. Lotti, M. de Kreuk, R. Kleerebezem, M. van Loosdrecht, J. Kruit, M.S.M. Jetten, B. Kartal, Nitrogen removal by a nitritation-anammox bioreactor at low 
temperature., Appl. Environ. Microbiol. 79 (2013) 2807-12. doi:10.1128/AEM.03987-12.

[6] S. Lackner, S. Welker, E.M. Gilbert, H. Horn, Influence of seasonal temperature fluctuations on two different partial nitritation-anammox reactors treating mainstream municipal wastewater, Water Sci. Technol. 72 (2015) 1358-1363. doi:10.2166/wst.2015.301.

[7] M. Laureni, P. Falås, O. Robin, A. Wick, D.G. Weissbrodt, J.L. Nielsen, T. a. Ternes, E. Morgenroth, A. Joss, Mainstream partial nitritation and anammox: Long-term process stability and effluent quality at low temperatures, Water Res. 101 (2016) 628-639. doi:10.1016/j.watres.2016.05.005.

[8] E. Isanta, C. Reino, J. Carrera, J. Pérez, Stable partial nitritation for low-strength wastewater at low temperature in an aerobic granular reactor., Water Res. 80 (2015) 149-58. doi:10.1016/j.watres.2015.04.028.

[9] B. Ma, S. Zhang, L. Zhang, P. Yi, J. Wang, S. Wang, Y. Peng, The feasibility of using a two-stage autotrophic nitrogen removal process to treat sewage., Bioresour. Technol. 102 (2011) 8331-4. doi:10.1016/j.biortech.2011.06.017.

[10] J. Pérez, E. Isanta, J. Carrera, Would a two-stage N-removal be a suitable technology to implement at full scale the use of anammox for sewage treatment?, Water Sci. Technol. 72 (2015) 858. doi:10.2166/wst.2015.281.

[11] C. Reino, M.E. Suárez-Ojeda, J. Pérez, J. Carrera, Kinetic and microbiological characterization of aerobic granules performing partial nitritation of a low-strength wastewater at $10^{\circ} \mathrm{C}$, Water Res. 101 (2016) 147-156. doi:10.1016/j.watres.2016.05.059.

[12] T. Awata, Y. Goto, T. Kindaichi, N. Ozaki, A. Ohashi, Nitrogen removal using an anammox membrane bioreactor at low temperature, Water Sci. Technol. 72 (2015) 2148-2153. doi:10.2166/wst.2015.436.

[13] T.L.G. Hendrickx, C. Kampman, G. Zeeman, H. Temmink, Z. Hu, B. Kartal, C.J.N. Buisman, High specific activity for anammox bacteria enriched from activated sludge at $10^{\circ} \mathrm{C}$, Bioresour. Technol. 163 (2014) 214-222. doi:10.1016/j.biortech.2014.04.025.

[14] M. Laureni, D.G. Weissbrodt, I. Szivák, O. Robin, J.L. Nielsen, E. Morgenroth, A. Joss, Activity and growth of anammox biomass on aerobically pre-treated municipal wastewater, Water Res. 80 (2015) 325-336. doi:http://dx.doi.org/10.1016/j.watres.2015.04.026.

[15] T. Lotti, R. Kleerebezem, C. van Erp Taalman Kip, T.L.G. Hendrickx, J. Kruit, M. Hoekstra, M.C.M. van Loosdrecht, Anammox growth on pretreated municipal wastewater., Environ. Sci. Technol. 48 (2014) 7874-80. doi:10.1021/es500632k.

[16] B. Ma, Y. Peng, S. Zhang, J. Wang, Y. Gan, J. Chang, S. Wang, S. Wang, G. Zhu, Performance of anammox UASB reactor treating low strength wastewater under 
moderate and low temperatures., Bioresour. Technol. 129 (2013) 606-11. doi:10.1016/j.biortech.2012.11.025.

[17] J. Dosta, I. Fernández, J.R. Vázquez-Padín, a Mosquera-Corral, J.L. Campos, J. Mata-Alvarez, R. Méndez, Short- and long-term effects of temperature on the Anammox process., J. Hazard. Mater. 154 (2008) 688-93. doi:10.1016/j.jhazmat.2007.10.082.

[18] M. Strous, J.G. Kuenen, M.S.M. Jetten, Key Physiology of Anaerobic Ammonium Oxidation Key Physiology of Anaerobic Ammonium Oxidation, Appl. Environ. Microbiol. 65 (1999) 0-3. doi:papers2://publication/uuid/E9A1573A-6D62-420E94D0-CA7C84D0FEB9.

[19] N. Morales, Á. Val del Río, J.R. Vázquez-Padín, R. Méndez, A. Mosquera-Corral, J.L. Campos, Integration of the Anammox process to the rejection water and main stream lines of WWTPs, Chemosphere. 140 (2015) 99-105. doi:10.1016/j.chemosphere.2015.03.058.

[20] I. Fernández, J.R. Vázquez-Padín, A. Mosquera-Corral, J.L. Campos, R. Méndez, Biofilm and granular systems to improve Anammox biomass retention, Biochem. Eng. J. 42 (2008) 308-313. doi:10.1016/j.bej.2008.07.011.

[21] M. Strous, J.J. Heijnen, G.J. Kuenen, M.M.S. Jetten, The sequencing batch reactor as a powerful tool for the study of slowly growing anaerobic ammonium-oxidizing microorganisms, Appl. Microbiol. Biotechnol. 50 (1998) 589-596. doi: $10.1007 / \mathrm{s} 002530051340$.

[22] W.R.L. van der Star, W.R. Abma, D. Blommers, J.-W. Mulder, T. Tokutomi, M. Strous, C. Picioreanu, M.C.M. van Loosdrecht, Startup of reactors for anoxic ammonium oxidation: experiences from the first full-scale anammox reactor in Rotterdam., Water Res. 41 (2007) 4149-63. doi:10.1016/j.watres.2007.03.044.

[23] Y. Liu, H. Lou Xu, S.F. Yang, J.H. Tay, Mechanisms and models for anaerobic granulation in upflow anaerobic sludge blanket reactor, Water Res. 37 (2003) 661673. doi:10.1016/S0043-1354(02)00351-2.

[24] L.W. Hulshoff Pol, S.I. De Castro Lopes, G. Lettinga, P.N.L. Lens, Anaerobic sludge granulation, Water Res. 38 (2004) 1376-1389. doi:10.1016/j.watres.2003.12.002.

[25] U. Imajo, T. Tokutomi, K. Furukawa, Granulation of Anammox microorganisms in up-flow reactors, Water Sci. Technol. 49 (2004) 155-164. http://wst.iwaponline.com/content/49/5-6/155.abstract.

[26] C.-J. Tang, P. Zheng, C.-H. Wang, Q. Mahmood, J.-Q. Zhang, X.-G. Chen, L. Zhang, J.-W. Chen, Performance of high-loaded ANAMMOX UASB reactors containing granular sludge., Water Res. 45 (2011) 135-44. doi:10.1016/j.watres.2010.08.018. 
[27] M.A. Latif, R. Ghufran, Z.A. Wahid, A. Ahmad, Integrated application of upflow anaerobic sludge blanket reactor for the treatment of wastewaters, Water Res. 45 (2011) 4683-4699. doi:10.1016/j.watres.2011.05.049.

[28] A.C. van Haandel, J.G.M. van der Lubbe, Handbook of Biological Wastewater Treatment: Design and Optimisation of Activated Sludge Systems, IWA Pub., 2012. https://books.google.es/books?id=RBLA8y6GGAMC.

[29] P. Arne Alphenaar, A. Visser, G. Lettinga, The effect of liquid upward velocity and hydraulic retention time on granulation in UASB reactors treating wastewater with a high sulphate content, Bioresour. Technol. 43 (1993) 249-258. doi:10.1016/0960-8524(93)90038-D.

[30] Y. Liu, J. Tay, The essential role of hydrodynamic shear force in the formation of biofilm and granular sludge, Water Res. 36 (2002) 1653-1665.

[31] L. Seghezzo, G. Zeeman, J.B. Van Liel, H.V.M. Hamelers, G. Lettinga, A REVIEW : The anaerobic treatment of sewage in UASB and EGSB reactors, 65 (1998) 175-190.

[32] R.C. Jin, G.F. Yang, C. Ma, J.J. Yu, Q.Q. Zhang, B.S. Xing, Influence of effluent recirculation on the performance of Anammox process, Chem. Eng. J. 200-202 (2012) 176-185. doi:10.1016/j.cej.2012.06.046.

[33] B.-S. Xing, Q. Guo, Z.-Z. Zhang, J. Zhang, H.-Z. Wang, R.-C. Jin, Optimization of process performance in a granule-based anaerobic ammonium oxidation (anammox) upflow anaerobic sludge blanket (UASB) reactor., Bioresour. Technol. 170 (2014) 404-12. doi:10.1016/j.biortech.2014.08.026.

[34] E. Isanta, T. Bezerra, I. Fernández, M.E. Suárez-ojeda, J. Pérez, J. Carrera, Bioresource Technology Microbial community shifts on an anammox reactor after a temperature shock using 454-pyrosequencing analysis, Bioresour. Technol. 181 (2015) 207-213. doi:10.1016/j.biortech.2015.01.064.

[35] A.A.V. van de Graaf, P. Debruijn, L. a Robertson, M.S.M. Jetten, J.G. Kuenen, Autotrophic growth of anaerobic ammonium-oxidizing micro- organisms in a fluidized bed reactor, Microbiology-Uk. 142 (1996) 2187-2196. doi:10.1099/13500872-142-8-2187.

[36] APHA, Standard Methods for the Examination of Water and Wastewater. Am. Water Work. Assoc. Water Environ. Fed. (2005).

[37] A. Dapena-Mora, I. Fernández, J.L. Campos, A. Mosquera-Corral, R. Méndez, M.S.M. Jetten, Evaluation of activity and inhibition effects on Anammox process by batch tests based on the nitrogen gas production, Enzyme Microb. Technol. 40 (2007) 859-865. doi:10.1016/j.enzmictec.2006.06.018.

[38] I. Jubany, J. Lafuente, J. Carrera, J.A. Baeza, Automated thresholding method (ATM) for biomass fraction determination using FISH and confocal microscopy, J. Chem. Technol. Biotechnol. 84 (2009) 1140-1145. doi:10.1002/jctb.2146. 
[39] J. Prehn, C.K. Waul, L.-F. Pedersen, E. Arvin, Impact of water boundary layer diffusion on the nitrification rate of submerged biofilter elements from a recirculating aquaculture system., Water Res. 46 (2012) 3516-24. doi:10.1016/j.watres.2012.03.053.

[40] M. Wanner, O., Eberl, H., Morgenroth, E., Noguera, D., Picioreanu, C., Rittmann, B., van Loosdrecht, Mathematical modeling of biofilms., Sci. Tech. Rep. No. 18. IWA Publ. London, UK. (2006).

[41] T. Lotti, R. Kleerebezem, C. Lubello, M.C.M. van Loosdrecht, Physiological and kinetic characterization of a suspended cell anammox culture, Water Res. 60 (2014) 1-14. doi:10.1016/j.watres.2014.04.017.

[42] H. Clippeleir, X. Yan, W. Verstraete, S.E. Vlaeminck, OLAND is feasible to treat sewage-like nitrogen concentrations at low hydraulic residence times, Appl. Microbiol. Biotechnol. 90 (2011) 1537-1545. doi:10.1007/s00253-011-3222-6.

[43] T.L.G. Hendrickx, Y. Wang, C. Kampman, G. Zeeman, H. Temmink, C.J.N. Buisman, Autotrophic nitrogen removal from low strength waste water at low temperature., Water Res. 46 (2012) 2187-93. doi:10.1016/j.watres.2012.01.037.

[44] T. Lotti, R. Kleerebezem, Z. Hu, B. Kartal, M.S.M. Jetten, M.C.M. Van Loosdrecht, ScienceDirect Simultaneous partial nitritation and anammox at low temperature with granular sludge, Water Res. 66 (2014) 111-121. doi:10.1016/j.watres.2014.07.047.

[45] T. Lotti, R. Kleerebezem, Z. Hu, B. Kartal, M.K. de Kreuk, C. van Erp Taalman Kip, J. Kruit, T.L.G. Hendrickx, M.C.M. van Loosdrecht, Pilot-scale evaluation of anammox-based mainstream nitrogen removal from municipal wastewater, Environ. Technol. 36 (2015) 1167-1177. doi:10.1080/09593330.2014.982722.

[46] D.-W. Gao, J.-C. Lu, H. Liang, Simultaneous energy recovery and autotrophic nitrogen removal from sewage at moderately low temperatures, Appl. Microbiol. Biotechnol. 98 (2014) 2637-2645. doi:10.1007/s00253-013-5237-7.

[47] F.J. Cervantes, Environmental Technologies to Treat Nitrogen Pollution, IWA Publishing, 2009. https://books.google.es/books?id=jUs9pG7PITQC. 
Figure captions and table legends

Fig. 1 Schematic diagram of the reactor set-up and the peripheral instrumentation. DO: dissolved oxygen.

Fig. 2 Continuous operation of the UAnSB reactor treating low-strength synthetic wastewater. (A) Nitrogen loading rate (NLR) and nitrogen removal rate (NRR); (B) Liquid upflow velocity; (C) Granule size evolution.

Fig. 3 Time course of the granule size distribution during the operation of the UAnSB reactor treating low-strength synthetic wastewater.

Fig. 4 Correlation of the diameter of the granules $\left(d_{g}\right)$ with the upflow liquid velocity $\left(\mathrm{V}_{\mathrm{up}}\right)$ applied in the UAnSB reactor. Correlation was obtained with data of periods II, III and IV of operation.

Fig. 5 Stratification of the granular sludge bed in the UASB anammox reactor treating low-strength synthetic wastewater. Missing values on day 203 and 248 were due to the lack of sampling at the corresponding heights.

Table 1. Periods of operation and operational parameters of the UASB anammox reactor. Since in periods I and III nitrogen loading rates were being increased and continuously changing, a range of NLR and NRR values was presented. (NLR = nitrogen loading rate; $\mathrm{NRR}=$ nitrogen removal rate; $\mathrm{N}_{\text {Tot effluent }}=$ total nitrogen concentration in the effluent; $\Delta \mathrm{N}-\mathrm{NO}_{2}{ }^{-} / \Delta \mathrm{N}-\mathrm{NH}_{4}{ }^{+}=$nitrite to ammonium consumption ratio; $\Delta \mathrm{N}-\mathrm{NO}_{3}{ }^{-} / \Delta \mathrm{N}-\mathrm{NH}_{4}{ }^{+}=$ nitrate produced to ammonium consumed ratio).

Table 2. Review of the NRR achieved in different reactors treating low-strength wastewater either in one or two-stage systems.

Table 3. Operational parameters of the UAnSB for each period and external mass transfer calculations. Granule diameter $\left(\mathrm{d}_{\mathrm{g}}\right)$, upflow velocity $\left(\mathrm{V}_{\mathrm{up}}\right)$, nitrogen removal rate $(\mathrm{NRR})$ and nitrite concentration in the bulk liquid are the experimental average values for each period. Reynolds (Re) and Sherwood number (Sh) were calculated with Eqs. (5) and (3), respectively. External mass transfer coefficient $\left(k_{c}\right)$ was calculated with Eq. (4) while external boundary layer was calculated with Eq. (2). 